\title{
The modelling of growth in the pig
}

\author{
P. J. Moughan ${ }^{1}$ and M. W. A. Verstegen ${ }^{2}$ \\ ${ }^{1}$ Department of Animal Science, Massey University, Palmerston North, New \\ Zealand \\ ${ }^{2}$ Department of Animal Nutrition, Wageningen Agricultural University, Haag- \\ steeg 4, NL 6708 PM Wageningen, Netherlands
}

Received 8 May 1987; accepted 7 January 1988

Key words: pig growth, simulation, modelling, feed utilization

\begin{abstract}
The methodology for applying pig growth models remains relatively undeveloped. A schematic approach has been followed to model pig growth from input of digested amino acids and of protein-free energy intake. Potential gain in protein and fat are used to calculate body weight gain, body composition and carcass composition. The major components of a generalized pig growth model have been discussed. The components discussed are body composition, energy and amino acid intake, utilization of amino acids, limits of protein retention, interaction between energy and amino acid intake, prediction of performance factors.

Future models are likely to develop these respective components or subsystems in greater detail. Output may be based on the concept of partitioning of daily dietary $\mathrm{N}$ and energy input in pig growth. Ultimately the control of fat and protein growth may be described in terms of cellular activity. It is concluded that future models should be more deductive than the present models.
\end{abstract}

\section{Introduction}

There has been much interest over recent years in simulating pig growth using computerized mathematical models. Baldwin (1976) urged the need for a systematic approach to model construction and identified the establishment of clear objectives as a necessary first step in modelling. Possible objectives for constructing a pig growth model are presented in Table 1.

The intended end-use of the model should influence the amount of detail included. The model should be as simple as possible to achieve the stated objective (Wright, 1971; Shannon, 1975). Given the current state of knowledge, however, there may be insufficient basic information on the digestion, metabolism and partitioning of nutrients in pigs to allow the construction of a model which fully meets all the objectives in Table 1. 


\section{P. J. MOUGHAN AND M. W. A. VERSTEGEN}

Table 1. Possible objectives for the development of a model simulating pig growth.

1. To allow an economic analysis of alternative feeding regimes for growing pigs

2. To allow comparison of actually recorded on-farm pig growth performance with 'potential' performance to indicate the extent of management/pig health problems

3. To demonstrate the relative economic consequences of adopting alternative farm-management strategies

4. To aid calculation of the relative economic values of unit improvement in genetic selection traits

5. To provide information on the physiological consequences of genetic improvement and to afford analysis of the effects on animal performance from genetic improvement or external manipulation of basic physiological traits

6. To aid in the design and interpretation of nutrition experiments

7. To demonstrate the principles of nutrient utilization and animal growth in the teaching of nutrition

8. To identify areas within the growth process where theoretical/empirical information is lacking - i.e. to provide a blueprint for future research

\section{Pig growth models}

The earliest models of animal growth were equations relating liveweight to age (Brody, 1945; Wilson, 1977). A common example is the logistic function, which along with similar curvilinear functions has been widely used to represent growth as a time-dependent drive towards a mature body weight.

Sometimes growth curves are based on simple pre-defined theories on the cause of growth but often they are purely mathematical fits to the experimental data. Considerable care must be exercised when making extrapolations, especially from the emperically-derived growth functions. Also, for a given set of data several growth curves may give equally good statistical fits yet have quite different shapes which may lead to false conclusions being drawn. The main criticism of the traditional growth curves, however, is that they do not include adequate description of the biological factors controlling growth (Taylor, 1978). Although such curves may adequately describe a particular experimental data set in a statistical sense and be useful for comparing animal growth patterns under strictly-defined conditions, they are of little value for predicting weights of animals growing under widely differing nutritional regimes.

The approach of Parks (1970) differs in that he treats the growth output not as a strict function of time but as a function of food input. Animal growth $(\mathrm{dW} / \mathrm{dt})$ is described as the product of food intake $(\mathrm{dF} / \mathrm{dt})$ and growth efficiency $(\mathrm{dW} / \mathrm{dF})$ :

$$
\frac{\mathrm{dW}}{\mathrm{dt}}=\frac{\mathrm{dW}}{\mathrm{dF}} \times \frac{\mathrm{Df}}{\mathrm{dt}}
$$

The growth rate function derived from the diminishing return functions for effi- 
ciency and ad libitum food intake can be integrated to give an S-shaped curve relating liveweight to age. The double exponential equation of Parks (1970) gives a close fit to experimental data and describes the accumulation of liveweight as being driven by age-dependent food intake. The traditional growth curve is now replaced with a three-dimensional $(\mathrm{W}, \mathrm{F}, \mathrm{t})$ growth 'trace' which is a function of four basic parameters: $\mathrm{A}=$ mature liveweight, $\mathrm{C}=$ food intake at maturity, $\mathrm{AB}=$ efficiency factor equal to the expected gain on the first unit of food eaten and $t^{*}=$ Brody's $t^{*}$ (a rate factor to maximum appetite). The Parks growth equation has been used to accurately describe the growth trace of quite diverse animal species, the differences between species being accounted for by differences in one or more of the four basic parameters. The effects of various experimental treatments can also be effectively described in terms of differences in the biologically interpretable growth parameters and the theory can be extended to include the case of restricted feeding. Parks (1982) has described the effects of dietary protein and energy contents on the respective parameters. Changes in the protein content of the diet at a constant energy level, has been shown to result in changes in $\mathrm{AB}$ but not in $\mathrm{A}, \mathrm{C}$ or $\mathrm{t}^{*}$ whereas change in the energy content of the diet at a constant level of protein led to changes in $\mathrm{C}$ and $\mathrm{AB}$ but not in $\mathrm{A}$ or $\mathrm{t}^{*}$. The effects of environmental temperature and genotype on animal growth have also been discussed (Parks, 1982).

Estimation of the Parks (1970) equation requires that long-term data, involving frequent measurement of liveweight and food intake, be collected (Wilson, 1977) thus requiring high inputs of labour and experimental facilities. The growth equation could be extended to allow prediction of protein and fat gains for pigs of different sex and genotype fed various combinations of nutrients and growing in different environments. Such an approach would be expensive and time-consuming, however, and would still not provide detailed insight into the underlying physiological mechanisms leading to the recorded responses.

Despite their inherent limitations, empirically based predictive equations have been developed for growing pigs and used in commercial practice. Carr et al. (1979) applied multiple regression analysis to data from a large-scale factorial growth trial and derived equations relating various response parameters (average daily liveweight gain. $\mathrm{ADG}$; backfat depth, $\mathrm{IC}_{4}$; killing-out percent, $\mathrm{K} 0$ ) to the average daily intakes of lysine (L) and digestible energy (E) for boars, gilts and castrates growing between 20 and $80 \mathrm{~kg}$ liveweight. Lysine was considered as a proxy for ideally balanced protein. Examples of the respective predictive equations in the case of the boars were:

$$
\begin{aligned}
& \mathrm{ADG}(\mathrm{g} / \mathrm{d})=-230.91+2.15 \mathrm{~L}+45.07 \mathrm{E}-1.98 \mathrm{~L}^{2}-1.46 \mathrm{E}^{2}+3.04 \mathrm{LE} \\
& \mathrm{IC}_{4}(\mathrm{~mm})=-9.67-1.091 \mathrm{~L}+2.561 \mathrm{E}+0.037 \mathrm{~L}^{2}-0.031 \mathrm{E}^{2}-0.028 \mathrm{LE} \\
& \mathrm{K} 0(\%)=53.54-0.297 \mathrm{~L}+2.230 \mathrm{E}-0.005 \mathrm{~L}^{2}-0.050 \mathrm{E}^{2}+0.013 \mathrm{LE}
\end{aligned}
$$

The above equations can be properly applied only to boars growing over the liveweight range of 20 to $80 \mathrm{~kg}$ in a thermoneutral environment and fed a single diet at 
set levels of intake between 60 and $95 \%$ of ad libitum digestible energy intake. The effect of pig genotype on growth was not investigated in the trial. The basic growth equations along with a function apportioning pigs to carcass grades were programmed onto a microcomputer and can be used to evaluate the economic consequences of variation in dietary digestible energy and lysine contents and feeding level for boars, gilts and castrates growing between 20 and $80 \mathrm{~kg}$ liveweight (Townsley, 1979; Ryan \& Ranaweera, 1984). This empirical model has been used widely in New Zealand for developing diets and feeding regimens for growing pigs to maximize profit in the face of fluctuating feed-ingredient and pig-meat prices. This model remains inflexible, however, in that many important variables which are known to affect growth cannot be included within the analytical framework.

In the quest for greater flexibility in growth prediction and to aid in the interpretation of the causative mechanisms of growth, 'biological' growth simulation models have been developed. The latter models which may contain both theoretical and empirical elements attempt to describe growth as the result of the action of basic physiological and biochemical processes and control points. Biological models can thus incorporate the effects of most external factors affecting growth in a fundamental manner.

Several biological pig growth models have been reported in the literature. On the one hand, biological models may describe the partitioning of food energy to chemical body components at a gross level (Whittemore \& Fawcett, 1974; Fowler, 1978; Menke, 1980; Phillips \& MacHardy, 1982; Metz et al., 1986) whereas at the opposite, extreme models have been developed (Kilburn et al., 1969; Schulz, 1978; Baldwin \& Black, 1979; Stombaugh \& Oko, 1980) which describe nutrient partitioning at the cellular level and include much biochemical detail. Between these two general categories there are several deterministic models which describe the basic nutrient partitioning process as being regulated by a few simple biochemical and physiological control points (Miller \& Payne, 1963; Whittemore \& Fawcett, 1976; Tess et al., 1983; Whittemore, 1983; Moughan \& Smith, 1984a; Black et al., 1986; Moughan et al., 1987a). Models of the latter type can be used to predict commercially important measures of animal performance, in face of variation in factors such as genotype, sex of the animal, level and quality of nutrition and physical climate. These models can be described in more detail by reference to a generalized flow diagram depicting nutrient digestion and utilization (Fig. 1).

The generalized model may be considered with respect to its components:

1. Body composition at the start of growth (Lo, Po, Wto, Ao).

2. Energy and amino acid intake $\left(\mathrm{E}_{I}, \mathrm{~A}_{\mathrm{I}}\right)$.

3. The utilization of ingested amino acids (steps $\mathrm{A}_{\mathrm{I}}$ to $\mathrm{Pg}$ ).

4. The influence of an upper-limit to protein retention (steps Pg to Pp).

5. Interaction between energy intake $\left(E_{I}\right)$ and protein $(P p)$ in the deposition of protein and lipid.

6. The prediction of performance factors (G, R, C, Le, Fa, GP).

This paper reviews the description of these components mainly with reference to the models of Whittemore \& Fawcett (1976), Whittemore (1983), Black et al. (1986) and Moughan et al. (1987a). 


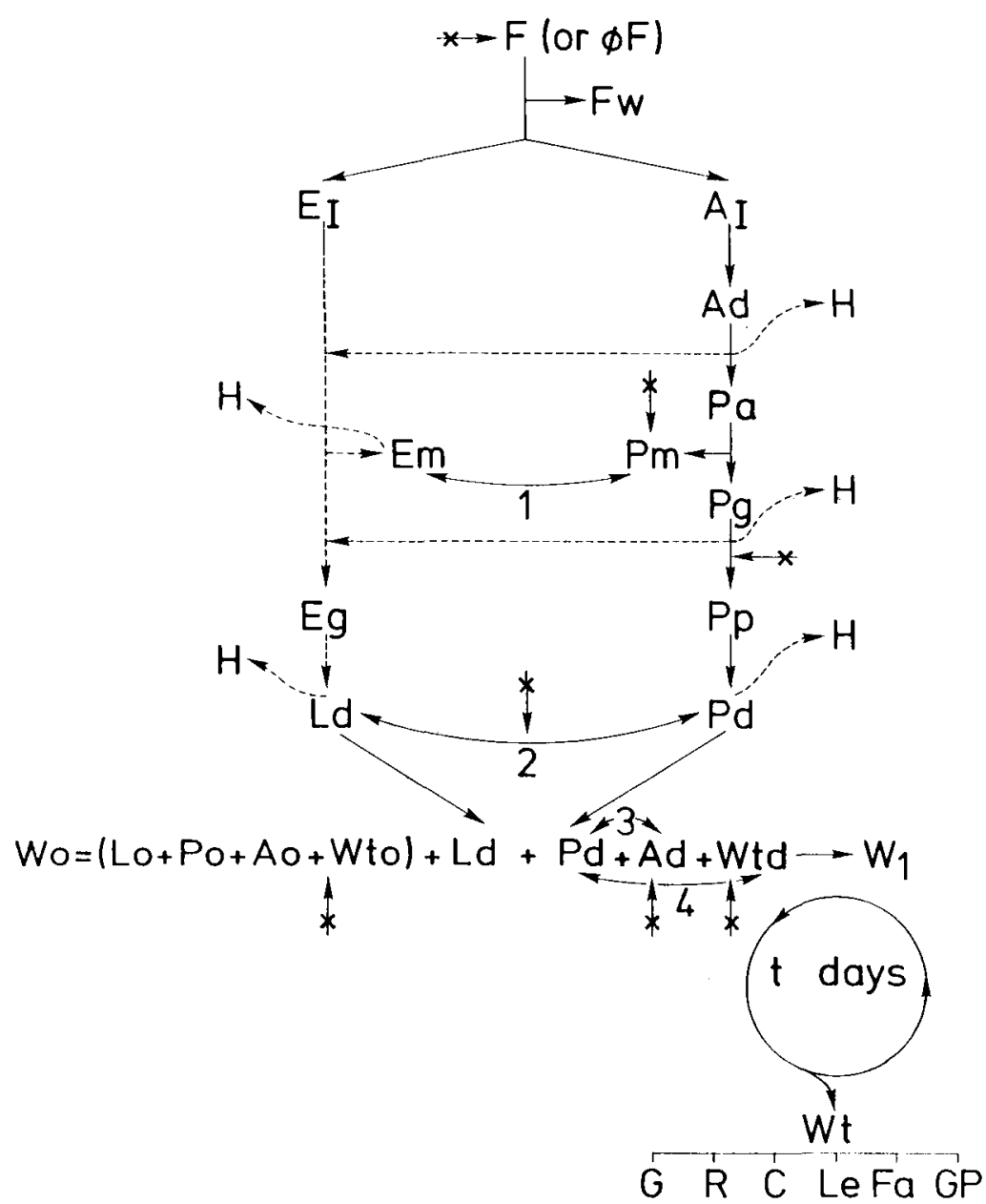

Fig. 1. A generalized biological model of nutrient flow in the growing pig incorporating physiological interactions and intrinsic factors affecting growth. Meaning of symbols: F - Food used under ad libitum feeding; $\varnothing \mathrm{F}$ - Food given (specified proportion of ad libitum); Fw - Food wastage; $\mathrm{E}_{1}-$ Protein-free energy intake (digestible); Em - Energy required for maintenance; $\mathrm{H}$ - Heat loss; Eg - Energy available for growth; $\mathrm{A}_{\mathrm{I}}$ - Amino acid intake; Ad - Digested amino acids; $\mathrm{Pa}$ - Balanced protein available for growth and maintenance; $\mathrm{Pm}$ - Protein required for maintenance; $\mathrm{Pg}$ - Balanced protein available for growth; Pp - Protein possibly deposited in face of diet constraint or constraint of upper limit to body protein retention (Pr); Pd - Protein deposited; Ld - Lipid deposited; Wo - Initial body weight containing lipid (Lo), protein (Po), ash (Ao) and water (Wto); Ad - Ash deposited; Wtd - Water deposited; W, Body weight at end of one day of growth; $\mathrm{Wt}$ - Body weight at end of $\mathrm{t}$ days; $\mathrm{G}$ - Average daily gain over the growth period ( $t$ days); $\mathrm{R}$ - Mean feed conversion ratio; $\mathrm{C}$ - Carcass weight; Le - Percent lean in the carcass; Fa - Percent fat in the carcass; GP - Grading profile; $\leftarrow 1 \rightarrow$ Interaction between protein turnover rate and $\mathrm{Em} ; \leftarrow 2 \rightarrow$ Interaction between dietary protein and energy; $\leftarrow 3 \rightarrow$ Interaction between ash and protein deposition; $\leftarrow 4 \rightarrow$ Interaction between water and protein deposition; $\longrightarrow$ Flow of material; -- - $\rightarrow$ Flow of energy; $\rightarrow$ Possible influence of genotype or sex. 


\section{Basic components of a generalized biological pig growth model}

\section{Body composition at the start of growth}

Pigs will normally enter the growing, finishing production stages at around 20 to 25 $\mathrm{kg}$ liveweight. Any model to predict the body composition of pigs at slaughter must specify the chemical composition at the start of simulated growth.

The studies of Manners \& McCrea (1963) and Elsley (1964) with suckled piglets have shown that post 7 days and up to 56 days of age, the proportions of protein and ash in the empty body remain very constant whereas the proportions of lipid and water are more variable. It has also been established (Whittemore et al., 1978; Tullis, 1981) that following weaning from the sow, piglets may lose substantial amounts of lipid yet continue to deposit muscle and bone. It seems, in accordance with the classical theory of growth, that there is a strong impetus in early life for body protein and mineral accretion.

The ability to regain body lipid lost at weaning will be influenced by nutrition and genotype. Zhang et al. (1986) showed that for pigs weaned at 3 weeks of age, the dietary DE:CP ratio had a marked effect on body lipid and water contents at 63 days of age (around $22 \mathrm{~kg}$ liveweight) but not on protein and ash. Further, Tess et al. (1986) found significant differences in body fat content at 10 weeks of age between different genetic stocks, but protein and ash contents were not influenced by genotype. Overall, it is expected that body lipid and water contents at $20 \mathrm{~kg}$ liveweight (Lo and Wto, respectively) may vary quite considerably between groups of pigs and between individuals within groups, whereas protein (Po) and ash (Ao) contents will be more constant.

This is supported by a survey of studies involving the chemical dissection of young pigs (Elsley, 1964; Wood \& Groves, 1965; Kotarbinska, 1968; De Wilde, 1976; Metz \& Dekker, 1981; Tullis, 1981; Tess et al., 1986; Zhang et al., 1986; P. J. Moughan \& W. C. Smith, unpublished data). The following ranges and average values for the chemical composition of the empty body (mean values) were calculated for pigs of around $20 \mathrm{~kg}$ liveweight:

- Pol:

- Lo':

range $=0.146-0.176$, average $^{2}=0.161$

$-\mathrm{Ao}^{1}$ :

- Wto':

range $=0.075-0.190$, average $^{2}=0.123$

range $=0.031-0.041$, average $^{3}=0.035$

Empty body weight/liveweight: range $=0.890-0.973$, average ${ }^{4}=0.945$

It will be important in a pig growth model to accomodate the variability in Lo which will be found in practice. Whittemore (1983) has approached this by giving three categories of body condition. The following values for chemical body composition at the start of simulated growth $(15-20 \mathrm{~kg}$ liveweight) were suggested:

\footnotetext{
${ }^{1}$ Expressed as a proportion of empty body weight. ${ }^{2}$ Average value of mean values from 21 groups of pigs. ${ }^{3}$ Average value of mean values from 13 groups of pigs. ${ }^{4}$ Average value of mean values from 7 groups of pigs.
} 
- Lo $\quad=0.07$ liveweight (thin pig)

- Lo $\quad=0.10$ liveweight (average condition)

- Lo $\quad=0.15$ liveweight (well-rounded pig)

- Po $\quad=0.134$ (empty body weight-body lipid $)^{1.120}$

- Ao $\quad=0.03$ liveweight

- Empty body weight $=0.95$ liveweight.

Moughan et al. (1987a) have used values similar to those of Whittemore (1983) but with a slightly wider range for Lo. In both models, Wto can be found as the difference between empty body weight at the start and the sum of Po, Lo and Ao. The models of Whittemore (1983) and Moughan et al. (1987a) assume that Lo is affected by factors such as age at weaning, nutritional history and genotype, and apportion pigs to three subjective categories of body condition. Black et al. (1986) describe Lo as a function of genotype and sex alone and estimate Po and W to as functions of fat-free empty body weight.

Whereas Lo may have an important effect on the early growth and development of pigs it is expected to have only a minor effect on growth performance and carcass characteristics at slaughther liveweights. Zhang et al. (1986), for example, found no effect of the initial body lipid content of pigs (nine weeks of age) on mean growth performance to $60 \mathrm{~kg}$ liveweight. It appears that the equations of Whittemore (1983), applied following the condition scoring of weaners whose growth is to be simulated should provide a suitable baseline for growth prediction. It may be worthwhile to investigate relationships between Lo and age at $20 \mathrm{~kg}$ liveweight as a more precise means of predicting Lo. Body lipid content in the $20 \mathrm{~kg}$ liveweight pig should be closely correlated with age.

\section{Energy and amino acid intake}

The amount of food eaten daily dictates the protein-free digestible energy $\left(E_{1}\right)$ and amino acid $\left(A_{I}\right)$ intakes which are the basic drives of growth.

Under restricted feeding regimes, the amount of food given per day $(\varnothing \mathrm{F})$ which is expressed as a proportion $(\varnothing)$ of ad libitum food usage $(F)$, less food wastage (Fw) will be used to predict daily food intake. Fw is likely to vary greatly in practice and Whittemore (1983) has suggested values of 0.025 to $>0.05$ food given. Although not represented as such in Fig. 1, there is some evidence ( $P$. Knap, pers. comm.) from observations on individually-fed pigs that Fw may be significantly influenced by sex of pig and genotype. Fw can have a large effect on weight gained per unit food given and being a highly variable factor may need to be measured for the situation being simulated.

$E_{I}$ and $A_{I}$ are calculated from a knowledge of daily food intake and the dietary nutrient composition. Dietary digestible energy content may be calculated based on tabulated values for the digestible energy contents of the ingredients or may alternatively be predicted from information on the proximate analysis of the diet (Morgan \& Whittemore, 1986). Rapid chicken TME and rat ADE, assays are useful for routinely determining the digestible energy contents of the commonly used 
cereals for growing pigs (Smith et al., 1987a, 1987b) but may be less satisfactory for predicting the digestible energy contents of high-fibre by-product feeds or diets containing the latter ingredients. For the amino acids, tabulated ingredient compositions may be used or preferably the mixed diet analysed. Even when amino-acid analysis is undertaken, an inter-laboratory coefficient of variation for the commonly first-limiting amino acid lysine as high as $11 \%$ and an intra-laboratory coefficient of variation of $2 \%$ can be expected (Happich et al., 1981).

For ad libitum feeding, daily food or energy intake will either be specified as an empirically-based function of liveweight (Whittemore, 1983) or predicted within the simulation model (Black et al., 1986). An estimate of Fw will be applied to derive the daily amount of food used $(\mathrm{F})$ under the ad libitum feeding regime.

The Agricultural Research Council (ARC, 1981) has collated 16 sets of data on the voluntary food intake of pigs and derived an exponential relationship between ad libitum digestible energy intake and liveweight. It was noted, however, that there was wide variation in the estimates of ad libitum intake both between and within experiments. Many factors are known to affect the voluntary food intake of pigs including dietary energy and protein concentrations, amino acid balance, type and level of dietary fibre, environmental temperature, form of the diet, penning density, feeder space, sex and genotype. Because of the likely differences in ad libitum digestible energy intake between individual pig farms, Moughan et al. (1987a) have not offered an empirical ad libitum food intake curve. Rather, it is suggested that the ad libitum digestible energy intake of pigs at two extreme liveweights be measured for the particular unit in question (monitor pens), and this information be used to adjust a standard ad libitum digestible energy intake function. The application of a statistical weighting procedure in a cattle growth model has been described by Oltjen \& Owens (1986).

Clearly, however, the approach of Moughan et al. (1987a) is not optimal, as the ad libitum digestible energy function is influenced by type of diet and one of the objectives of using models in a nutritional setting is to determine the required diet composition. Also, the physiological interconnections between growth and ad libitum food intake are of much interest to geneticists. It would be useful, then, to be able to predict daily ad libitum food intakes based on a description of the basic biological control mechanisms.

The model of Black et al. (1986) gives the metabolizable energy intake of the pig as a function of productive potential (thus including the influence of sex and genotype) with further regulation being exerted by gut capacity, environmental temperature (high and low) and dietary amino acid content. The latter model appears to predict at least the average ad libitum food intakes of pigs growing over specified liveweight ranges rather accurately, but it is notable that the authors still include a scale factor in their model to adjust predicted ad libitum food intake to that observed on-farm. The concept that an animal ingests food to satisfy nutrient requirements for a potential level of production is also inherent in the work of Forbes (1977) on ruminants and Emmans $(1981,1985,1986)$ on chickens. The predictive accuracy of this approach needs thorough in-field evaluation, but offers promise as a means of predicting daily ad libitum food intake for pigs. The theoretical ap- 
proach of Toates \& Booth (1974) to describing daily food intake and feeding frequency in the rat also merits investigation for application to the growing pig.

\section{The utilization of ingested amino acids}

A proportion of the ingested amount of each amino acid will be absorbed into the portal blood of the growing pig and will be transported to the sites of body protein synthesis. Depending upon the pattern of absorbed amino acids in relation to a pattern required for the combined processes of resynthesizing lost protein and synthesizing new protein in the idealized 'typical' body cell, a fraction of the absorbed amino acids will be unavailable for protein synthesis and will be deaminated in the liver and the nitrogenous component excreted as urinary urea. Part of the 'balanced' protein $(\mathrm{Pa})$ will be used to cover the cell's requirement for protein maintenance $(\mathrm{Pm})$ with the remaining balanced protein $(\mathrm{Pg})$ being available for new body protein synthesis.

Whittemore (1983) suggested that the absorbed level of each amino acid be determined by applying a value for the apparent faecal digestibility of dietary crude protein. In the absence of a diet-specific value for digestible crude protein, a standard coefficient of 0.85 was recommended. The ileal method, however, is the preferred way of measuring amino acid digestibility (Low, 1980; Rerat, 1981; Moughan \& Smith, 1985; Van Weerden et al., 1985; Sauer \& Ozimek, 1986) particularly when more poorly digested feedstuffs are used. There may be large differences between apparent faecal crude protein digestibility and the apparent ileal digestibility of individual amino acids. For example, in meat and bone meal which is relatively poorly digested by the growing pig, Moughan (1984) determined an apparent faecal crude protein digestibility of 0.81 but an apparent ileal digestibility for lysine of 0.65 and for threonine of 0.55 . Differences of this magnitude may lead to large discrepancies in the prediction of absorbed amino acids. Lenis (1983) in reviewing the world literature, also found a lack of agreement between mean faecal crude protein digestibility and the mean ileal digestibilities of individual amino acids. Close agreement between faecal and ileal values was found for some amino acids in some feedstuffs, although large discrepancies were also reported, particularly in the case of threonine and tryptophan. Jörgensen et al. (1985) concluded that the ileal digestibility of at least lysine, methionine and threonine may be able to be predicted, using regression relationships, from information on the faecal digestibility of crude protein.

Moughan \& Smith (1984a) and Moughan et al. (1987a) have specified the use of apparent ileal amino acid digestibility estimates pertaining to the individual dietary ingredients. Information on the ileal digestibility of amino acids in several of the commonly used pig feedstuffs is now available for application in growth modelling, but data are still sparse for many by-product feeds (Lenis, 1983). Furthermore, it appears that use of the laboratory rat may allow routine inexpensive determination of ileal protein digestibility for the pig (Moughan et al., 1984; Picard et al., 1984; Moughan et al., 1987b). True ileal amino acid digestibility would be a refinement over apparent values but further work on gut endogenous amino acid excretion is 
required before a routine assay for true digestibility can be developed.

In the Australian pig growth model, Black et al. (1986) determine absorbed amino acids by use of lysine availability measurements. It is a problem, however, that estimates of amino acid availability for the various pig feed ingredients are not well known and the method for determining amino acid availability is open to criticisms (Austic, 1983). Also, the assumption of Black et al. (1986) that the measure of lysine availability will apply to all dietary amino acids is unlikely to hold true.

If there is a large difference between amino acid availability and ileal digestibility then use of an availability measurement may be justified, but for most ingredients used in practice this is not expected to be the case (Austic, 1983).

The balanced protein available for growth and maintenance ( $\mathrm{Pa}$ ) is calculated in essentially the same manner by Miller \& Payne (1963); Whittemore \& Fawcett (1976); Whittemore (1983); Black et al. (1986) and Moughan et al. (1987a). A chemical score based on the ratio of the concentration of the first limiting absorbed amino acid ( $\mathrm{g} / \mathrm{kg}$ crude protein) to the required level ( $\mathrm{g} / \mathrm{kg}$ of reference crude protein) is used to determine Pa. In their earlier model, Moughan \& Smith (1984a) made allowance for the transamination of essential amino acids to non-essentials if the dietary non-essential amino acid component was limiting. Depending upon the objectives of model use this may be an important consideration. There is some evidence that the application of chemical score may not always give accurate estimates of $\mathrm{Pa}$ (Fuller et al., 1983). Whittemore (1983) suggested that it may be worthwile to adjust chemical score downwards depending upon the degree of over-supply of certain amino acids. It remains unclear, however, as to the actual effect of a small degree of amino acid imbalance on the utilization of the limiting amino acid (Boorman, 1980).

The chemical score value and thus $\mathrm{Pa}$ and ultimately the output parameter Pd can be highly influenced by the reference level of the first-limiting amino acid. A sensitivity analysis of growth model parameters (Moughan, 1985) indicated that a $10 \%$ change in the reference level of the first-limiting amino acid led to around a $12 \%$ increase or decrease in Pd. Differences in Pd of this magnitude will have a very significant effect on the prediction of growth rate, feed conversion efficiency and carcass quality. It is of critical importance, therefore, to accurately quantify the amino acid composition of the reference protein.

Whittemore $(1976,1983)$ has suggested the use of either pig whole-body essential amino acid composition or the ARC (1981) recommendation for ideal amino acid balance as the reference amino acid pattern. Black et al. (1986) use whole body amino acid composition while Moughan \& Smith (1984a) and Moughan et al. (1987a) have applied an estimate of ideal amino acid balance (Moughan \& Smith, 1984b) based on results from three experiments specifically designed to determine ideal amino acid balance for the growing pig (Lewis \& Cole, 1976; Fuller et al., (1979; Low, 1981). There are large differences between whole-body amino acid composition and the empirical estimates of ideal amino acid balance for several key amino acids (Moughan \& Smith, 1987a). The acceptance of whole-body amino acid composition as the reference pattern assumes that loss of body amino acids at maintenance is either insignificant in relation to total amino acid requirement or that 
amino acids are lost from the body in similar proportion to their presence in wholebody protein. These assumptions, however, may be contested. Direct summation of the amounts of amino acids used for maintenance and growth processes in the pig (Moughan, 1987) indicates that the use of amino acids for processes other than the synthesis of new body protein, may lead to a reference pattern of amino acids different to that based on whole-body protein. Also, the reference or 'ideal' amino acid pattern may vary depending on the daily rate of body protein retention. Particularly at lower levels of body protein retention, the amino acid requirements for maintenance protein synthesis can be expected to have a large effect on the reference pattern. Although an empirical estimate of ideal amino acid balance may provide a satisfactory reference pattern for prediction of $\mathrm{Pa}$ for pigs depositing relatively high levels of body protein, both the empirical and whole-body protein estimates of ideal amino acid balance appear unsuitable for general application. Further, an empirical estimate of ideal amino acid balance determined for pigs growing over the liveweight range 20 to $80 \mathrm{~kg}$, may not be appropriate for animals growing over lower ranges of liveweight (Smith et al., 1986; Moughan et al., 1987c).

Balanced protein required to replace obligatory nitrogen loss via the urine and skin (Pm) has been calculated (Whittemore, 1983; Black et al., 1986) as a function of metabolic body weight $\left(\mathrm{Pm}=0.94 \mathrm{~W}^{0.75}\right)$ following the conclusions of the review of Carr et al. (1977). Moughan \& Smith (1984a) used a slightly higher estimate (Pm $\left.=1.06 \mathrm{~W}^{0.75}\right)$. If apparent amino acid digestibility coefficients are employed in a model, then endogenous amino acid loss via the intestines is accounted for, albeit in a crude fashion. However, if true digestibility coefficients are applied then the intestinal amino acid loss will need to be directly described in the model.

Whittemore (1983) gives an alternative equation for the calculation of $\mathrm{Pm}$, based on total body protein $(\mathrm{Pm}=0.004 \mathrm{Pt})$. This has the advantage of generating different values of Pm for pigs of equal weight but of different sex and genotype. Whittemore \& Fawcett (1976) described protein maintenance requirements as a proportion of body protein breakdown rate which also covers differences between sexes and genotypes in terms of their total body protein contents at a given age but allows expression of the effect of an increased rate of protein deposition on the rate of protein turnover and therefore Pm.

\section{The upper limit to daily protein retention}

In a situation where dietary energy is not limiting for protein deposition, some models such as the general mammalian growth model of Miller \& Payne (1963) and the chicken growth model of Scheele et al. (1977) predict that total balanced protein available for growth, $\mathrm{Pg}(\mathrm{Pg}=\mathrm{Pa}-\mathrm{Pm})$ may be deposited in the body. The pig growth models of Whittemore \& Fawcett (1976); Whittemore (1983); Moughan \& Smith (1984a); Black et al. (1986) and Moughan et al. (1987a), however, assume that there is an intrinsic upper-limit to body protein retention ( $\mathrm{Pr}$ ) which is influenced by genotype and sex. Excess $\mathrm{Pg}(\mathrm{Pg}>\mathrm{Pr})$ is deaminated and the nitrogen excreted in the urine. If $\mathrm{Pg}<\mathrm{Pr}$ then the amount of protein that can potentially be deposited (Pp) equals Pg. If, however, $\mathrm{Pg}>\mathrm{Pr}$, then $\mathrm{Pp}=\operatorname{Pr}$. 
Whittemore \& Fawcett (1976) and Moughan \& Smith (1984a) have assumed that below Pr, Pg is used with complete efficiency. This is an oversimplification. For example, the ARC (1981) whose findings have been discussed further by Fuller \& Chamberlain (1983), concluded that as ideal protein intake increases, the efficiency of utilization of ideal protein for protein deposition in the pig decreases in a curvilinear manner.

When $\mathrm{Pg}<\mathrm{Pr}$ and dietary energy is not limiting (i.e. there is not an 'excessive' deamination of amino acids for purpose of energy production) then the inefficient utilization of $\mathrm{Pg}$ will be due in large part to the 'inevitable' loss of amino acids to deaminative pathways. Following the theory of enzyme saturation kinetics and the law of mass action it is expected that the efficiency of utilization of Pg will decline curvilinearly as Pg approaches Pr. Miller \& Payne (1963) have included this effect directly in their model by describing the 'inevitable' breakdown of protein for energy (Ie) as a linear function of dietary protein concentration $\left(\mathrm{Ie}^{\prime}=\mathrm{kP}\right.$; where $\mathrm{Ie}^{\prime}$ is Ie expressed as a proportion of total protein consumed, $\mathrm{k}=0.019$ and $\mathrm{P}$ is protein calories percentage of total calories). Whittemore (1983) has introduced an efficiency factor, $\mathrm{a}(\mathrm{a}=0.85$ to 0.90$)$ such that $\mathrm{Pg}_{1}=(\mathrm{Pg} \times \mathrm{a})$. If $\mathrm{Pg}_{1}>\operatorname{Pr}$ then $\mathrm{Pp}=\mathrm{Pr}$; if $\mathrm{Pg}_{1}<\operatorname{Pr}$ then $\mathrm{Pp}=\mathrm{Pg}_{1}$.

The existence of the parameter $\operatorname{Pr}$ has been difficult to demonstrate experimentally. Recently, however, information has become available (Campbell et al., 1983; Campbell et al., 1984a; Dunkin et al., 1984; Campbell, 1985) which clearly demonstrates that $\operatorname{Pr}$ is an important constraint on protein growth in pigs and that Pr is affected by sex of the pig and by genotype. At least for some pigs growing between 20 and $90 \mathrm{~kg}$ liveweight it was possible to demonstrate a plateau to daily protein deposition rate $(\mathrm{Pd})$ when the intake of a protein-adequate diet was increased towards ad libitum. If in these trials it is assumed that $\mathrm{Pd}$ at plateau is not being restrained by nutrient intake, environmental factors or by carry-over effects from early nutrition, which seems likely, then Pd must be controlled by an intrinsic factor (Pr). It has been more difficult to demonstrate the existence of $\mathrm{Pr}$ in pigs below 20 kg liveweight fed cereal-based diets (Campbell \& Dunkin, 1983). Hodge (1974), however, fed $10 \mathrm{~kg}$ liveweight pigs a protein-adequate liquid milk diet and found no change in nitrogen retention when energy intake was raised from four to five times maintenance.

Whittemore (1983) has reviewed studies in which Pd could be considered close to Pr and gives values for Pr ranging from 90 to $175 \mathrm{~g} /$ day. Differences in Pr between sexes and genetic strains of pigs are also suggested. The study of Campbell (1985) indicates that for very well-bred boars Pr may exceed 187 grams per day. Just (1971) measured body protein deposition rate in females and castrated-males of the Danish Landrace breed receiving adequate dietary amino acid intakes and moderate energy intakes. Between 20 and $90 \mathrm{~kg}$ liveweight, the females deposited an average $101 \mathrm{~g}$ protein/day and the castrates $94 \mathrm{~g} /$ day. Wiesemuller (1983) reported $\mathrm{Pr}$ values for growing pigs of $74 \mathrm{~g}$ protein/day for castrates $(40-120 \mathrm{~kg}$ liveweight $), 96$ $\mathrm{g} /$ day for gilts $(30-120 \mathrm{~kg})$ and $123 \mathrm{~g} /$ day for entire-males $(30-120 \mathrm{~kg})$.

In addition to having mean estimates of Pr for pigs growing over specified liveweight ranges it is important in growth modelling to be able to describe the relation- 
ship between Pr and liveweight.

Several workers (Thorbek, 1975; Carr et al., 1977) have derived relationships between $\mathrm{Pd}$ and liveweight and it is generally accepted that $\mathrm{Pd}$ increases rapidly in early life, plateaus during the grower/finisher stages and then decreases towards zero at maturity. There should be little argument that after the point of decline in $\mathrm{Pd}$, Pd will be regulated by $\mathrm{Pr}$ and measurement of $\mathrm{Pd}$ should equate with $\mathrm{Pr}$. The relationship between $\mathrm{Pd}$ and liveweight before the point of decline, however, does not necessarily describe the relation between Pr and liveweight. At a given liveweight it is often difficult to establish that Pr has actually been reached. This has led workers to adopt a more pragmatic approach to estimating Pr. Measurements of Pd at different liveweights for pigs fed high-quality diets ad libitum and kept under optimum environmental conditions are accepted as values of $\operatorname{Pr}$ (Tullis, 1981; Black et al., 1986; Siebrits et al., 1986). The conclusions drawn by these workers vary due in part, no doubt, to differences between the breeds and strains studied but also to the method of curve-fitting adopted.

The functions derived by Tullis (1981) and Black et al. (1986) demonstrate that Pr declines towards zero at maturity from around 100 to $110 \mathrm{~kg}$ liveweight, whereas the curves of Siebrits et al. (1986) show an earlier decline in $\mathrm{Pr}$ - from around $60 \mathrm{~kg}$ liveweight for obese gilts, $75 \mathrm{~kg}$ liveweight for lean boars and gilts and $100 \mathrm{~kg}$ liveweight for obese boars. Taking the results from these three studies together, it appears that determined Pr is broadly constant between 45 and $90 \mathrm{~kg}$ liveweight. The data from these experiments and particularly observations relating to the early growth stages (birth to $100 \mathrm{~kg}$ liveweight) must be interpreted with caution, however, because measured Pd ('determined' Pr) may be lower than actual Pr. By using a different diet or by altering some environmental condition, it is possible that $\mathrm{Pd}$ at a given liveweight may be increased.

Although time-consuming and expensive, the more fool-proof approach to determining the relationship between Pr and liveweight would be to attempt to establish the attainment of Pr at selected liveweights using the procedure outlined earlier (Campbell et al., 1983). It would also seem preferable to derive relationships over a wide range of liveweights (birth or weaning to maturity) and to fit curves, the equations for which include readily interpretable biological parameters. For practical purposes, however, the pragmatically defined estimates of $\operatorname{Pr}$ are likely to be quite satisfactory for inclusion in growth models. In practice, ad libitum food intakes during early growth are likely to be lower than those found under experimental conditions and the upper-limit to Pd will effectively be set by predicted food intake.

To conclude and in the absence of more definite information on the way in which Pr changes with age in the pig, there is no reason to disband the simple hypothesis of Whittemore (1983) that Pr for a pig of defined sex and genotype is essentially constant between 20 and $100 \mathrm{~kg}$ liveweight. Because of the significance of the parameter $\operatorname{Pr}$ to the accuracy of model predictions, it becomes imperative that the values for Pr be determined for diverse populations of pigs. A routine method for determining the body protein content of live pigs would be a considerable aid in the measurement of Pr. A lack of suitable data on $\mathrm{Pr}$, inevitably hampers application of a growth model in practice. 


\section{Interaction between metabolizable energy and protein in the deposition of body lipid and protein}

Because protein synthesis costs energy while protein can also be used as a source of available energy, there is an interaction during growth between the utilization of dietary protein-free energy and protein.

As shown in Fig. 1, imbalanced protein (Ad-Pa) and protein supplied in excess of $\operatorname{Pr}(\mathrm{Pg}-\mathrm{Pp})$ is deaminated and the net yield of energy can be considered to join the protein-free digestible energy intake $\left(\mathrm{E}_{\mathrm{I}}\right)$ to give a flow of metabolizable energy $\left(\mathrm{ME}_{\mathrm{I}}\right)$.

The protein-free digestible energy intake $\left(\mathrm{E}_{\mathrm{l}}\right)$ may be overestimated if conventional measures of digestibility are used, especially for high-fibre diets. During fermentation there will be losses of energy in the form of heat and methane, and faecal digestible energy measurement will record these losses as though they were absorbed energy available for metabolism. Black et al. (1986) make adjustment for this loss of energy as methane and heat, based on the dietary level and digestibility of neutral detergent fibre. Disagreement exists, however, as the appropriate correction factors. The flow of metabolizable energy $\left(\mathrm{ME}_{\mathrm{I}}\right)$ will be first used to meet the animal's energy requirement for maintenance with the residual energy, under conditions of thermoneutrality, being used by the animal for the synthesis of new body tissues.

\section{Energetic costs of maintenance and tissue deposition}

The simplest way of describing maintenance energy cost $(\mathrm{Em})$ is as a function of metabolic liveweight (Moughan \& Smith, 1984a). This approach is inflexible, however, in that it does not account for differences in Em for pigs of different sex and genotype. As a large part of Em is likely to be related to body protein turnover, it seems more appropriate to give $\mathrm{Em}$ as a function of total body protein (Whittemore, 1983). The latter approach has in turn been criticized by Black et al. (1986) because it does not include the effect of growth rate (see Baldwin, 1976). Animals which are growing faster and depositing more protein at a given body protein mass are expected to have higher rates of protein turnover and thus higher values for Em. Black et al. (1986) include this effect along with a lag factor for change in Em, when a change in growth rate occurs. The effect of body protein turnover rate on the energy metabolism of the growing pig is also inherent in the work of Whittemore \& Fawcett (1976).

Most growth models have used empirically derived estimates of the total energy costs of depositing protein and lipid (ep and el, respectively). In the case of ep, literature values are highly variable whereas values for el are more consistent (Tess, 1981). There is also a marked discrepancy between theoretical and empirical values of ep. The empirical values of ep have usually been determined following the statistical apportioning of metabolizable energy intake to maintenance and lipid and protein retentions. This method has several widely recognized shortcomings. The parameters Em, ep and el are all highly correlated, energy retained as protein is a small fraction of total metabolizable energy, the values of ep and el are affected by 
diet composition and the estimates of ep are likely to vary with age, liveweight and rate of liveweight gain. Following estimation by the multiple regression procedure, the value for ep is likely to contain a variable part of the cost of protein turnover. It may be more logical when modelling growth to include the complete energy cost of protein turnover as part of maintenance. The energy requirements for basal metabolism ('maintenance') and protein and lipid synthesis may be expressed in terms of the theoretical requirements for moles of ATP (Schulz, 1978; Machiels \& Henken, 1986). The 'above-basal' increase in rate of protein turnover can be predicted and the theoretical energy cost (ATP) added to the 'maintenance' cost. Low environmental temperature or an increased level of physical activity would increase basal metabolic rate. This approach would also allow a direct description of the differential efficiency of utilization of absorbed nutrients. Van Es (1980) has shown for example that $74 \mathrm{KJ}$ of glucose ME are required to supply one mole of ATP whereas $78 \mathrm{KJ}$ of fatty acid $\mathrm{ME}$ and $93 \mathrm{KJ}$ of volatile fatty acid $\mathrm{ME}$ are required to give the same one mole of ATP. Further, description of the uptake of individual nutrients allows simulation of the relatively highly efficient processes of direct synthesis. Some of the absorbed fatty acids are synthesized directly into lipid and some glucose to glycogen. A problem with the theoretical approach, however, is that the ATP costs particularly for protein synthesis are contentious (Van Es, 1980). Also, there is still a lack of reliable information on basal energy losses and the factors affecting these in the growing pig, and body protein turnover remains a difficult process to measure.

\section{The partitioning of energy}

For the apportionment of $\mathrm{ME}_{\mathrm{l}}$ between maintenance and lipid and protein deposition, two general approaches may be followed. In the classical approach, $\mathrm{ME}_{\mathrm{I}}$ is apportioned firstly to maintenance $(\mathrm{Em})$ with the remaining energy being considered as available for growth $(\mathrm{Eg})$. Energy contained in the protein to be deposited $(\mathrm{Pd}=$ $\mathrm{Pp})$ is added to $\mathrm{E} g$ and the total energy supply $\left(\mathrm{E}_{\mathrm{T}}\right)$ is apportioned firstly to meet the total energy cost of protein deposition, with residual energy being apportioned to body lipid $(\mathrm{Ld})$. The latter approach implies that $\mathrm{Pd}$ is dependent on $\mathrm{Pp}$ and independent of $\mathrm{E}_{\mathrm{T}}$. This, however, is not always the case and a second physiological state is possible whereby $\mathrm{E}_{\mathrm{T}}$ limits $\mathrm{Pd}$. Here, $\mathrm{Pd}$ is independent of Pp but dependent on the level of $\mathrm{E}_{\mathrm{T}}$. A proportion of the amount of protein $\mathrm{Pp}$ will be deaminated to provide metabolizable energy, thus there is an interaction between the dietary protein and protein-free energy contents. A pig growth model will need to include description of this possible situation of 'excessive' deamination of amino acids for energy supply.

Whittemore (1983) has given a possible basis for the interaction between dietary protein and protein-free energy in terms of a physiological requirement for a certain minimal level of daily lipid deposition. If following the 'classical' approach to energy partitioning, residual energy is not sufficient to meet this minimum lipid deposition requirement then it is proposed that deamination of protein is triggered and protein is degraded to supply energy for lipid synthesis.

The minimum lipid constraint is specified in terms of a minimum ratio between 
daily lipid and protein deposition rates and is assumed to be affected by sex and genotype of the pig (Whittemore, 1983). It is possible that the ratio may alo be affected by age and liveweight. Expression of the minimum lipid rule in terms of whole-body lipid content rather than daily lipid gain (Whittemore \& Gibson, 1983; Moughan \& Smith, 1984a; Moughan et al., 1987a) appears more realistic and provides for a description of body lipid catabolism. Empirical support for the existence and action of the minimum lipid to protein constraint is provided by the results from a recent comparative slaughter trial (Campbell et al., 1984b) in which growing boars were given diets of differing crude protein concentration at two levels of food intake. The data from this trial have been discussed in detail in relation to the model constraint (Moughan, 1984).

Whenever total energy intake is limiting for potential body growth and energy intake may potentially limit body protein deposition, Black et al. (1986) predict the amount of body protein which may be deposited daily by applying empirical relationships between protein gain and metabolizable energy intake. Different relationships are found for pigs of different liveweight and it is likely that there will be different slopes of the functions for pigs of varying genotype. The slopes (energydependent phase of growth) are apparently a reflection of the minimum Ld:Pd ratio applying during pig growth.

\section{Prediction of performance factors}

As shown in the generalized flow diagram of a growth model (Fig. 1) the emptybody weight of a pig at the end of the first day's growth $\left(\mathrm{W}_{1}\right)$ can be found by summing Wo, Ld, Pd, daily ash deposited (Ad) and daily water deposited (Wtd). Ad is likely to be closely related to $\mathrm{Pd}$ and it is often assumed that Wtd is a function of $\mathrm{Pd}$, the form of the particular relationships being affected by the sex of the pig and genotype. Equations which may be used to predict Ad and Wtd respectively, have been reviewed by Whittemore (1983). Often, however, the effects of sex, breed and strain within breed are poorly quantified. Also, body water retention is affected by the level of lipid as well as protein retention and apparently small errors in the prediction of daily body water gain may have a significant influence on the prediction of liveweight.

At the end of $t$ days of growth the mean growth rate $(G)$, feed conversion ratio (R) and carcass weight (C) may be calculated. Carcass weight can be predicted solely as a function of liveweight (after $t$ days growth) and body fatness (Whittemore, 1983) or the effect of diet type (as reflected by dietary energy density) on gutsize and gut-fill may be included (Black et al., 1986). The definition of a pig carcass will vary between slaughter points, thus limiting the value of a single predictive equation. It would seem to be useful to work towards a complete characterization of the body components lost from the empty body at slaughter and then to directly predict the killing out percentage for any specified method of slaughter.

Carcass quality has usually been simulated by calculation of a backfat measurement (e.g. $\mathrm{P}_{2}$, measured $65 \mathrm{~mm}$ from the mid-line at the head of the last rib) and a limited amount of information, relating $\mathrm{P}_{2}$ to body fat content for pigs of different 
genotype and body-compositional type, is available (Whittemore, 1983). More detail on the effects of sex, breed and strain on the relationship between $\mathrm{P}_{2}$ and total body lipid, no doubt reflecting differences in the relative importance of the various fat depots, is required. The proportions of the total population of slaughter pigs falling into various grade categories (based on carcass weight and backfat measurement), that is the grading profile (GP), can be found by application of a function describing the normal distribution (Moughan et al., 1987a). It may sometimes be required to predict the percent lean and fat in the carcass (Le and $\mathrm{Fa}$, respectively) and predictive equations are available (Whittemore, 1983). Because of the likely effect of breed and strain of pig on carcass quality measures and because of peculiarities in different carcass classification systems, it may be necessary for individual countries or regions to derive their own relationships for inclusion in pig growth models. The respective predicted performance values can ultimately be used to calculate financial outputs such as gross or net margins.

\section{Conclusion}

Once a growth model has been constructed and programmed and the computer programme checked for internal accuracy (verification), the model must be validated. Rationalistic, empirical and positivistic philosophies should all be included in the approach to validation (Shannon, 1975). Validation should be an on-going procedure allied to model development (Dent \& Blackie, 1979) and the performance of a model must be assessed in relation to the objectives of model construction. Statistical approaches to validation have been discussed (Naylor \& Finger, 1967; Mihram, 1972; Penning de Vries, 1977). For statistical tests to be meaningful it is required that the values of the variables which affect growth are identical in the real and modelled systems. This condition may be very difficult to achieve in practice and consequently a statistically significant difference between real and modelled output should not necessarily be interpreted as invalidating a model.

Although the theoretical framework for a model of pig growth is now well established it should be apparent that there are several areas where information is incomplete or lacking. In spite of this, models of the type described here have been used to accurately predict pig performance in practice (Black et al., 1986; Moughan et al., 1987a). This demonstrates that although a model may generate acceptably accurate predictions, it is not necessarily a correct representation of reality. The veracity of current models should be improved by giving further attention to the description of model components. In fact a prime function of models is to facilitate the identification of key parameters affecting growth, via the conduct of a sensitivity analysis (Shannon, 1975; Moughan, 1985). France \& Thornley (1984) have described a dimensionless quantity which may be applied to assess the sensitivity of model output to variation in the values of model parameters. Parts of the growth process in pigs which particularly merit detailed investigation are: (1) the upperlimit to body protein retention (Pr); (2) the utilization of dietary amino acids (steps $\mathrm{A}_{\mathrm{I}}$ to $\mathrm{Pa}$ ); (3) the maintenance energy requirements (Em); and (4) the relationships between body water and protein and lipid contents. 
The methodology for 'on farm' application of validated and suitably robust models remains relatively undeveloped, though some aspects have been discussed (Whittemore \& Elsley, 1976; Gibson, 1978; Moughan \& Smith, 1987b).

The approach adopted in the present review has been to examine the description of the major components of a generalized pig growth model. Future models are likely to develop these respective sub-systems in greater detail and there should be a move towards description at a more biochemical and cellular level. Ultimately the control of fat and protein growth may be described in terms of the cellular activities of key fat-synthesizing enzymes and ribosomal RNA concentrations, respectively (Burleigh, 1980). In general and wherever possible, models should be less empirical and more deductive in nature (Whittemore, 1986).

The effects of many factors known to influence pig growth (e.g. environmental temperature) have not been discussed here, but it should be noted that a biological growth model will allow ready inclusion of such factors as long as their effects on model parameters can be quantified. Also, the present discussion has been confined to deterministic models describing growing pigs. Already, however, models describing pig performance from birth to maturity have been developed (Tess et al., 1981; Black et al., 1986) and in the future it is likely that stochastic description will become increasingly important.

\section{Acknowledgement}

P. J. Moughan wishes to thank the Wageningen Agricultural University for sponsoring a lecture course on growth modelling. The present paper was prepared in conjunction with this course.

\section{References}

Agricultural Research Council. 1981. The nutrient requirements of pigs. Commonwealth Agricultural Bureaux, Slough, England, $154 \mathrm{pp}$.

Austic. R. E.. 1983. The availability of amino acids as an attribute of feeds. In: G. E. Robards \& R. G. Packham (Eds). Feed information and animal production, p. 175-189. Commonwealth Agricultural Bureaux, Slough, England.

Baldwin. R. L., 1976. Principles of modelling animal systems. Proceedings of the New Zealand Society of Animal Production 36: 128-139

Baldwin, R. L. \& J. L. Black, 1979. Simulation of the effects of nutritional and physiological status on the growth of mammalian tissues: Description and evaluation of a computer program. Animal Research Laboratories Technical paper No 6, CSIRO, Melbourne, 35 pp.

Black, J. L., R. G. Campbell, I.H. Williams, K. J. James \& G. T. Davies, 1986. Simulation of energy and amino acid utilization in the pig. Research and Development in Agriculture 3: 121-145.

Boorman, K. N., 1980. Dietary contraints on nitrogen retention. In: P. J. Buttery \& D. B. Lindsay (Eds), Protein Deposition in Animals, p. 147-166. Butterworths, London.

Brody, S., 1945. Bioenergetics and growth. Reinhold, New York, $1023 \mathrm{pp}$

Burleigh, I. G., 1980. Growth curves in muscle nucleic acid and protein: Problems of interpretation at the level of the muscle cell. In: T. L. J. Lawrence (Ed.), Growth in animals, p. 101-136. Butterworths, London.

Campbell, R. G., 1985. Effects of sex and genotype on energy and protein metabolism in the pig. In: R. B. Cumming (Ed.), Recent Advances in Animal Nutrition in Australia, 1985. University of New England Publishing Unit, Armidale, Australia. 
Campbell, R. G. \& A. C. Dunkin, 1983. The influence of dietary protein and energy intake on the performance, body composition and energy utilization of pigs growing from 7 to $19 \mathrm{~kg}$. Animal Production 36: 185-192.

Campbell, R. G., M. R. Taverner \& D. M. Curic, 1983. The influence of feeding level from 20 to $45 \mathrm{~kg}$ liveweight on the performance and body composition of female and entire male pigs. Animal Production 36: 193-199.

Campbell, R. G., M. R. Taverner \& D. M. Curic, 1984a. The effects of sex and of energy intake on rate of protein deposition in growing pigs. Animal Production in Australia 15: 660.

Cambell, R. G., M. R. Taverner \& D. M. Curic, 1984b. Effect of feeding level and dietary protein content on the growth, body composition and rate of protein deposition in pigs growing from 45 to $90 \mathrm{~kg}$. Animal Production 38: 233-240.

Carr, J. R., K. N. Boorman \& D. J. A. Cole, 1977. Nitrogen retention in the pig. British Journal of Nutrition 37: 143-155.

Carr, J. R.. G. Pearson, J. L. Adam \& R. J. Townsley, 1979. The growth of the pig. Massey University, Palmerston North, New Zealand, 87 pp.

De Wilde, R., 1976. Study of a method for the determination of protein and energy retentions in pigs by means of carcass analysis. Mededelingen Fakulteit Diergeneeskunde 3-4, University of Gent (in Dutch), $211 \mathrm{pp}$.

Dent, J. B. \& M. J. Blackie, 1979. Systems simulation in agriculture. Applied Science Publishers, London, $180 \mathrm{pp}$.

Dunkin, A. C., J. L. Black \& K. J. James, 1984. Relationship between energy intake and nitrogen retention in the finisher pig. Animal Production in Australia 15: 672.

Elsley, F. W. H., 1964. The physiological development of the young pig, p. 75-84. Séminaire International, l'Institut National de la Recherche Agronomique, Paris.

Emmans, G. C., 1981. A model of the growth and feed intake of ad libitum fed animals, particularly poultry. In: G. M. Hillyer, C. T. Whittemore \& R. G. Gunn (Eds), Computers in animal production. p. 103-110. British Society of Animal Production, Surrey, England.

Emmans, G. C., 1985. A general method to predict the unconstrained food intake of an immature animal. Animal Production 40: 569

Emmans, G. C., 1986. A model of the food intake. growth and body composition of pigs fed ad libitum. Animal Production 42: 471.

Es, A. J. H. van, 1980. Energy costs of protein deposition. In: P. J. Buttery \& D. B. Lindsay (Eds), Protein Deposition in Animals, p. 215-224. Butterworths, London.

Forbes, J. M., 1977. Interrelationships between physical and metabolic control of voluntary food intake in fattening, pregnant and lactating mature sheep: A model. Animal Production 24: 91-101.

Fowler, V. R., 1978. Biological models of quantifying growth and efficiency. In: H. De Boer \& J. Martin (Eds), Patterns of growth and development in cattle, p. 325-351. Martinus Nijhoff. The Hague.

France, J. \& J. H. M. Thornley, 1984. Mathematical models in agriculture. Butterworths, $335 \mathrm{pp}$.

Fuller, M. F. \& A. G. Chamberlain, 1983. Protein requirements of pigs. In: W. Haresign (Ed.), Recent advances in animal nutrition, p. 175-186. Butterworths, London.

Fuller, M. F. R. M. Livingstone, B.A. Baird \& T. Atkinson, 1979. The optimal amino acid supplementation of barley for the growing pig. 1. Response of nitrogen metabolism to progressive supplementation. British Journal of Nutrition 41 : 321-331.

Fuller, M. F., A. Cadenhead, K. H. Chen, J. Milne \& De Brown, 1983. Evaluation of proteins for growing pigs by reference to ARC ideal protein. In: R. Pion, M. Arnal \& D. Bonin (Eds). Proceedings th international symposium on protein metabolism and nutrition, Clermont-Ferrand (France). 5-9 September 1983, Vol. 2, p. 427-430. Institut National de la Recherche Agronomique. Paris.

Gibson, A., 1978. Performance prediction. In: Proceedings of a Meat and Livestock Commission: Conference of the East of Scotland College of Agriculture, 1978, p. 50-61.

Happich, M. L., C. E. Bodwell \& J. G. Phillips, 1981. Collaborative studies of amino acid analyses: a review and preliminary observations from a nine-laboratory study. In: C. E. Bodwell, J. S. Adkins. D. T. Hopkins (Eds), Protein quality in humans: assessment and in vitro estimation, p. 197-220. AVI Publishing Company, Connecticut

Hodge, R. W., 1974. Efficiency of food conversion and body composition of the pre-ruminant lamb and the young pig. British Journal of Nutrition 32: 113-126. 


\section{P. J. MOUGHAN AND M. W. A. VERSTEGEN}

Jorgensen, H., J. A. Fernandez \& A. Just, 1985. Relation between ileal and faecal digestible nutrients in 96 diets for pigs. In: A. Just, H. Jorgensen \& J. A. Fernandez (Eds), Proceedings of the 3rd international seminar on digestive physiology in the pig (Copenhagen) p. 352-355. National Institute of Animal Science, Copenhagen.

Just Nielsen, A., 1971. Protein requirement of growing pigs determined by nitrogen balance experiments and slaughter investigations. Copenhagen Royal Veterinary and Agricultural University Yearbook 1971: 81-97.

Kilburn, D. G., M. D. Lilly \& F. C. Webb, 1969. The energetics of mammalian cell growth. Journal of Cell Science 4: 645-654.

Kotarbinska, M., 1968. The chemical composition of the body in growing pigs. European Association of Animal Production Meeting. Subcommission on pig progeny testing, Dublin, $7 \mathrm{pp}$.

Lenis, N. P., 1983. Faecal amino acid digestibility in feedstuffs for pigs. In: R. Pion, M. Arnal \& D. Bonin (Eds), Proceedings 4th international symposium on protein metabolism and nutrition, ClermontFerrand (France), 5-9 September 1983, Vol. 2, p. 385-389. Institut National de la Recherche Agronomique, Paris.

Lewis, D. \& D. J. A. Cole, 1976. Quantitative aspects of pig nutrition. Amino acid requirements. Proceedings of the Nutrition Society 35: 87-91.

Low, A. G., 1980. Nutrient absorption in pigs. Journal of the Science of Food and Agriculture 31: 10871130.

Low, A. G. 1981. Amino acid use by growing pigs. In: W. Haresign (Ed), Recent advances in animal nutrition, p. 141-156. Butterworths, London.

Machiels, M. A. M. \& A. M. Henken, 1986. A dynamic simulation model for growth of the African Catfish, Clarias gariepinus (Burchell 1822). I. Effect of feeding level on growth and energy metabolism. Aquaculture 56: $29-52$.

Manners, M. J. \& M. R. McCrea, 1963. Changes in the chemical composition of sow-reared piglets during the first month of life. British Journal of Nutrition 17: 495-513.

Menke, K. H., 1980. A system for prediction of retention of protein and fat in growing animals. In: L. E. Mount (Ed), Energy metabolism, p. 175-178. Butterworths, London.

Metz, S. H. M. \& R. A. Dekker, 1981. The contribution of fat mobilization to the regulation of fat deposition in growing Large White and Pietrain pigs. Animal Production 33: 149-157.

Metz, S. H. M., F. W. Kamphuis, A. C. M. Mentink, E. Kanis, C. M. C. van de Peet-Schwering \& M. W. A. Verstegen, 1986. Simulation of growth performance in growing, fattening pigs. 37th Annual Meeting of the European Association for Animal Production (Budapest), paper 5-4.

Mihram, G. A., 1972. Some practical aspects of the verification and validation of simulation models. Operational Research Quarterly 23: 17-29.

Miller, D. S. \& P. R. Payne, 1963. A theory of protein metabolism. Journal of Theoretical Biology 5: 398--411.

Morgan, C. A. \& C. T. Whittemore, 1986. Growth response prediction in relation to optimization of pig meat production. 37th Annual Meeting of the European Association of Animal Production (Budapest), 1 paper $5-5$.

Moughan, P. J., 1984. Aspects of dietary protein quality for the growing pig. Ph.D. thesis, Massey University, Palmerston North, New Zealand, 193 pp.

Moughan, P. J.. 1985. Sensitivity analysis on a model simulating the digestion and metabolism of nitrogen in the growing pig. New Zealand Journal of Agricultural Research 28: 463-468.

Moughan. P. J.. 1987. Simulation of the daily partitioning of amino acids in the $50 \mathrm{~kg}$ liveweight pig. In: Proceedings of the Australasian Pig Science Association Inaugural Conference, Albury, November 1987, (in press).

Moughan. P. J. \& W. C. Smith. 1984a. Prediction of dietary protein quality based on a model of the digestion and metabolism of nitrogen in the growing pig. New Zealand Journal of Agricultural Research 27: 501-507.

Moughan, P. J. \& W. C. Smith, 1984b. Assessment of a balance of dietary amino acids required to maximise protein utilisation in the growing pig (20-80 kg liveweight). New Zealand Journal of Agricultural Research 27: 341-347.

Moughan, P. J.\& W. C. Smith, 1985. Determination and assessment of apparent ileal amino acid digestibility coefficients for the growing pig. New Zealand Journal of Agricultural Research 28: 365-370. 
Moughan, P. J. \& W. C. Smith, 1987a. A note on the whole-body amino acid composition of the growing pig. New Zealand Journal of Agricultural Research (in press).

Moughan, P. J. \& W. C. Smith, 1987b. A dynamic approach to estimating nutrient requirements for growth in pigs and poultry. In: Proceedings 4th Animal Science Congress of the Asian-Australasian Association of Animal Production Societies, p. 23-26, Hamilton, New Zealand.

Moughan, P. J., W. C. Smith \& K. A. C. James, 1984. Preliminary observations on the use of the rat as a model for the pig in the determination of apparent digestibility of dietary protein. New Zealand Journal of Agricultural Research 27: 509-512.

Moughan, P. J., W. C., Smith \& G. Pearson, 1987a. Description and validation of a model simulating growth in the pig (20-90 kg liveweight). New Zealand Journal of Experimental Agriculture (in press).

Moughan, P. J., W. C. Smith. A. K. Kies \& K. A. C. James, 1987b. Comparison of the ileal digestibility of amino acids in ground-barley for the growing rat and pig. New Zealand Journal of Agricultural Research 30: 59-66.

Moughan. P. J., W. C. Smith \& J. K. Cornwell, 1987c. Determination of the biological value of a protein source with a supposedly ideal amino acid balance (ARC, 1981) for the young pig (10 to $20 \mathrm{~kg}$ liveweight). Journal of the Science of Food and Agriculture 38: 91-96.

Naylor, T. H. \& J. M. Finger, 1967. Verification of computer simulation models. Management Science 14: $92-101$

Oltjen. J. W. \& F. N. Owens. 1986. Beef cattle feed intake and growth: Application of an empirical Bayes derivation of the Kalman filter applied to a non-linear dynamic model. In: Animal Science Research Report. May 1986, p. 101-106. Agricultural Experiment Station, Oklahoma State University, Oklahoma. USA.

Parks. J. R.. 1970. Growth curves and the physiology of growth. I. Animals. American Journal of Physiology 219: 833-836.

Parks, J. R. 1982. A theory of feeding and growth of animals. Springer-Verlag, Berlin, $322 \mathrm{pp}$.

Penning de Vries, F. W. T., 1977. Evaluation of simulation models in agriculture and biology: conclusions of a workshop. Agricultural Systems 2: 99-107.

Phillips. P. A. \& F. V. MacHardy, 1982. Modelling protein and lipid gains in growing pigs exposed to low temperature. Canadian Journal of Animal Science 62: 109-121.

Picard. M., S. Bertrand, M. Duron \& R. Maillard, 1984. Comparative digestibility of amino acids using 5 animal models: Intact cockerel, caecectomised cockerels, rat deprived of large intestine, piglet with an ileo caecal cannulation, piglet with an ileo rectal shunt. In: Proceedings of the IVth European Symposium on Poultry Nutrition. Tours, France, p. 165.

Rerat. A., 1981. Digestion and absorption of nutrients in the pig. World Review of Nutrition and Dietetics 37: 229-287.

Ryan, O. P. \& K. N. P. Ranaweera, 1984. Nutritional manipulation of body composition in non-ruminant farm animals. Proceedings of the Nutrition Society of New Zealand 9: 50-54.

Sauer. W. C. \& L. Ozimek. 1986. Digestibility of amino acids in swine: Results and their practical applications. A review. Livestock Production Science 15: 367-388.

Scheele. C. W.. W. M. M. A. Janssen \& L. van Gils, 1977. Feeding criteria for prediction of growth and carcass composition. In: K. N. Boorman \& B. J. Wilson (Eds), Growth and poultry meat production, p. 249-259. British Poultry Science, Edinburgh.

Schulz. A. R.. 1978. Simulation of energy metabolism in the simple-stomached animal. British Journal of Nutrition 39: 235-254.

Shannon, R. E. 1975. Systems simulation, the art and science. Prentice Hall, New Jersey, 387 pp.

Siebrits. F. K.. E. H. Kemm. M. N. Ras \& P. M. Barnes, 1986. Protein deposition in pigs as influenced by sex, type and livemass. 1. The pattern and composition of protein deposition. South African Journal of Animal Science 16: 23-27.

Smith. W. C.. P. J. Moughan \& G. Pearson. 1986. Effect on pig performance of decreasing amino acid levels in practical grower diets of equal lysine content. New Zealand Journal of Agricultural Research 29: $243-248$.

Smith, W. C., P. J. Moughan, G. Pearson \& M. R. Patchell, 1987a. Relationships between pig apparent digestible (ADE) and metabolizable (AME) energy values and chicken true metabolizable (TME) energy values of several ground cereal grains. In: Proceedings 4th Animal Science Congress of the Asian-Australasian Association of Animal Production Societies, Hamilton, New Zealand, p. 468. 


\section{P. J. MOUGHAN AND M. W. A. VERSTEGEN}

Smith, W. C., P. J. Moughan, G. Pearson \& K. A. C. James, 1987b. Comparative bioavailable energy values of five ground cereal grains measured with growing rats and pigs. Animal Feed Science and Technology: in press.

Stombaugh, D. P. \& A. Oko, 1980. Simulation of nutritional-environmental interactions in growing swine. In: L. E. Mount (Ed.), Energy metabolism, p. 209-215. Butterworths, London.

Taylor, St., C. S., 1978. Methods of quantifying growth and development: General review. In: H. De Boer \& J. Martin (Eds), Patterns of growth and development in cattle, p. 625-638. Martinus Nijhoff, The Hague.

Tess, M. W.. 1981. Simulated effects of genetic change upon life-cycle production efficiency in swine and the effects of body composition upon energy utilization in the growing pig. Ph.D. thesis, University of Nebraska, Nebraska, USA, $315 \mathrm{pp.}$

Tess, M. W., G. L. Bennett \& G. E. Dickerson, 1983. Simulation of genetic changes in life cycle efficiency of pork production. 1. A bioeconomic model. Journal of Animal Science 56: 336-353.

Tess, M. W.. G. E. Dickerson. J. A. Nienaber \& C. L. Ferrell, 1986. Growth, development and body composition in three genetic stocks of swine. Journal of Animal Science 62: 968-979.

Thorbek. G.. 1975. Studies on energy metabolism in growing pigs. Beretning fra statens Husdyrbrugs forsog. 424. Copenhagen.

Toates, F. M. \& D. A. Booth. 1974. Control of food intake by energy supply. Nature 251: 710-711.

Townsley, R. J., 1979. Economic analysis of feeding regimes for growing pigs. In: The growing pig and its influence on profitable pig production, p. 11-23. Pfizer New Zealand Ltd, Auckland.

Tullis, J. B., 1981. Protein growth in pigs. Ph.D. thesis, University of Edingburgh, Scotland. 183 pp.

Weerden. E. J. van. J. Huisman. P. van Leeuwen \& P. Slump, 1985. The sensitivity of the ileal digestibility method as compared to the faecal digestibility method. In: A Just, H. Jorgensen \& J. A. Fernandez (Eds). Proceedings of the 3rd international seminar on digestive physiology in the pig. Copenhagen, 16-18 May 1985, p. 392-395. National Institute of Animal Science, Copenhagen.

Whittemore, C.T., 1976. A study of growth responses to nutrient inputs by modelling. Proceedings of the Nutrition Society 35: 383-391.

Whittemore, C. T., 1983. Development of recommended energy and protein allowances for growing pigs. Agricultural Systems 11: 159-186.

Whittemore, C. T., 1986. An approach to pig growth modelling. Journal of Animal Science 63: 615-621.

Whittemore, C. T. \& F. W. H. Elsley, 1976. Practical Pig Nutrition. Farming Press Ltd, Suffolk, England, $190 \mathrm{pp}$.

Whittemore, C. T. \& R. H. Fawcett, 1974. Model responses of the growing pig to the dietary intake of energy and protein. Animal Production 19:221-231.

Whittemore, C. T. \& R. H. Fawcett, 1976. Theoretical aspects of a flexible model to simulate protein and lipid growth in pigs. Animal Production 22: 87-96.

Whittemore, C.T. \& A. Gibson, 1983. A growth model for pigs designed to include recent concepts of nutrient requirement. Animal Production 36: 516.

Whittemore, C. T. A. Aumaitre \& I. H. Williams, 1978. Growth of body components in young weaned pigs. Journal of Agricultural Science, (Cambridge) 91: 681-692.

Wiesemuller, W., 1983. Physiological basis of the protein requirements of pigs. Critical analysis of allowances. In: R. Pion, M. Arnal \& D. Bonin (Eds), Proceedings 4th international symposium on protein metabolism and nutrition, Clermont-Ferrand (France), 5-9 September 1983. Vol. 1. p. 405431. Institut National de la Recherche Agronomique, Paris.

Wilson, B. J.. 1977. Growth curves, Their analysis and use. In: K. N. Boorman \& B. J. Wilson (Eds), Growth and poultry meat production, p. 89-115. British Poultry Science Ltd, Edinburgh.

Wood, A. J. \& T. D. D. Groves, 1965. Body composition studies on the suckling pig. 1. Moisture, chemical fat, total protein and total ash in relation to age and body weight. Canadian Journal of Animal Science 45: 8-13.

Wright, A., 1971. Farming systems, models and simulation. In: J. B. Dent \& J. R. Anderson (Eds), Systems analysis in agricultural management, p. 17-33. John Wiley, Sydney.

Zhang, Y., I. G. Partridge \& K. G. Mitchell, 1986. The effect of dietary energy level and protein: energy ratio on nitrogen and energy balance, performance and carcass composition of pigs weaned at 3 weeks of age. Animal Production 42: 389-395. 